UDC 339.138:379.85

http://doi.org/10.21272/mmi.2019.2-14

JEL Classification: M31, Z32

Panita Preechawong,

Shinawatra University, Thailand

Ousanee Sawagvudcharee,

Shinawatra University, Thailand

Bahaudin G. Mujtaba,

Nova Southeastern University, USA

\title{
MARKETING AND MANAGING DESTINATION IDENTITY FOR TOURISM PROMOTION: THE CASE OF KOH CHANG MARINE NATIONAL PARK IN THAILAND
}

Abstract. Tourism industry in Thailand is important for economic activity and for determining the regional policy of the country. Tourism is likely to increase its contribution to the GDP from its already significant role of more than $10 \%$. Local people get undeniable benefits from tourism in their economic and social environments. The management of tourism destination has become more important for stakeholders, especially in terms of destination identity of tourism. Koh Chang Marine National Park (KCMNP) stakeholders, both senders and receivers, emphasize the importance of destination identity. The development and use of a strong destination identity is critical when making strategic marketing plans. The information the tourist uses to make their decision can come from a stakeholder's focus in managing destination identity. Effective management will improve KCMNP's revenues on a long-term sustainable basis, as well as, ensure that the local community gets the benefits associated with a successful tourist destination in the form of more tasks, better jobs, improved services, and increased quality of life. A qualitative content analysis of data is conducted in this study, to identify key requirements and components of Koh Chang Marine National Park's stakeholders. The main research results and recommendations are provided along with suggestions for future research. The tourism industry in KCMNP requires improvement in order to provide a better tourism destination identity. An improved destination identity can help KCMNP effectively share its message to potential tourists, ultimately stabilizing and growing the number of visitors every year. It is necessary though, that this activity be actively supported by the stakeholder community and tourists. Koh Chang Marine National Park is one of 127 national parks in Thailand. In the past, it was a very popular destination, and Chang Island, as the largest most developed island in the park, benefitted the most. However, in recent years, tourist arrivals to national park have significantly decreased from its peak in 2010. Koh Chang Marine National Park (KCMNP) is a 42-island archipelago in the Gulf of Thailand. It is located in Trat Province in the eastern region of Thailand close to the Cambodian border, nearly 8 kilometres from shore. Its most significant tourist destination is called Chang Island or Koh Chang. The Island, the second largest in Thailand after Phuket was declared a district of Trat province in August 2007. Because of its size and prominence as the second largest island in the kingdom, there are many visitors. In the past, the island, while technically uninhabited, was used as a port to escape the monsoon, as well as, provision resources. Later on, the Island was developed as a tourist destination and was designated a national park on $31^{\text {st }}$ December 1982 to become the $45^{\text {th }}$ national park in Thailand. This study aims to gain insight into the situation behind the lacklustre arrival numbers and to explore the recognition of both the sender side and receiver side of KCMNP's stakeholders. This should help identify key issues that will allow facilitate the development of suitable guidelines to generate a strong, viable destination identity. Analysis of resources, competencies and capabilities of the locale are the basis from which the destination brand identity can be developed. This study tries to determine the key components of destination identity of Koh Chang Marine National Park? The objective of this study is to better understand the perception of stakeholders about KCMNP using interview questions as a base for research.

Keywords: destination identity, stakeholders' recognition, marketing and managing destination identity.

Introduction. When people travel, they visit new places and make new friends, which can help them increase their sense of self-worth (Buckley, 2010). Travel and tourism can also lead to new reflections, learning, and better experiences regarding society, fun, pleasure, fairness, and overall workplace equity (Huang, Ryan and Mujtaba, 2015; Hallak, Assaker and Lee, 2015). Some define their perfect holidays as

Cite as: Preechawong, P., Sawagvudcharee, O., \& Mujtaba, B. G. (2019). Marketing and Managing Destination Identity for Tourism Promotion: The Case of Koh Chang Marine National Park in Thailand. Marketing and Management of Innovations, 2, 160 172. http://doi.org/10.21272/mmi.2019.2-14 
one where they increase their personal knowledge, gain new experiences, and widen their personal horizon or perspective. In addition, travel holidays are opportunities to create memories that last a lifetime, ultimately making them happier people.

The perception of tourism economic is so important that it has become the fastest growing industry in the 21 st century. Rajesh (2013) explains that it is very important to determine the destination image while making decisions for the strategic marketing of tourism destinations because it is likely to result in a positive image of the specific destination, as well as loyalty to tourist location and overall satisfaction by the tourists. The positive results lead to increased profits which helps all business owners, workers, and the local government.

Tourism has a massive attraction that helps middle- and lower-income populations to get involved in both domestic and international tourism development (Hallak, Assaker and Lee, 2015). A good tourism experience by customers (sender stakeholders) can positively change people's bank accounts (business owners and employees on the receiver side of stakeholder group), and alter attitudes to create a more satisfying climate for family members and colleagues, while also increasing the motivation of all workers by being more receptive to the changes and needs of the local/global community.

People recognize the value of travel, and the global tourist industry has grown and developed to the point where it has become a significant business. Moreover, tourism has the potential to produce revenue in virtually every country on the planet. It can also play a significant role in each country's economic development. The main benefits of tourism is that it brings in direct revenues and increased jobs to people within the industry.

Tourism development is important to determine regional policy of almost all countries. The management of tourism destination has become more important for stakeholders especially, in term of destination identity of these tourist attractions and locations (Rajesh, 2013). Tourism industry is a major economic sector of Thailand and has grown stronger for several centuries. For KCMNP, tourism and hospitality industries are the most significant sources of jobs and play a leading economic role for the local population. Both management and development must be balanced against the need for environmental protection, which helps ensure the sustainability of the island as a tourist destination.

Literature Review. Most tourism related employees tend to work for very small firms and owneroperated companies which make up about $90 \%$ of all businesses in Asia-Pacific, Australia, United States, and Europe (Mujtaba, 2014; Hallak, Assaker and Lee, 2015). These small and medium tourism enterprises (SMTEs), that are delivering valued-added experiences through a recognized brand, tend to be the economic engines of tourism destinations and local communities. The sustainable performance of SMTEs is «critical to the success of the tourism sector and for the livelihood of tourism destinations» (Hallak, Assaker and Lee, 2015, p. 36). As such, it is important for policy makers and entrepreneurial leaders to create a consistent, memorable, and sustainable brand identity for their destination.

Bregoli (2012) found that destination identity is based on the collective views of local communities and business operators. A well-designed destination identity seems to create a sense of belonging to the people who live and work in the community. An appropriate process for creating destination identity is important in order to attract tourists domestically as well as internationally. Some researchers state that destination identity is important in the overall success of a tourist destination. Cai (2002) and Mak (2011) studied the creation of destination identity to determine its importance as the components can emerge from involvement and participation in the branding process. Saraniemi (2011) said that destination identity is often captured from the user's point of view, namely, the tourists themselves. Therefore, it can be concluded that destination identity comes from the perception of several supply-side stakeholders (receivers) combined with the point of views of tourists (senders) regarding the destination.

Destination: Pike (2004) said that destination is a place that attracts travellers for a momentary stay, to participate in tourism related activities or perhaps, non-activities. Destination can be a more 
perceptual concept, which is a subjective viewpoint by consumers. Buhalis (1999) stated that a destination can be gathered together as combination or a brand of all products, services and locally provided experiences. This can be developed within the "Six A's» framework for tourism destination analysis: attraction, accessibility, amenities, availability, activities, and ancillary. Framke (2002) defined destinations as a part of the tourism system. In this way, any particular destination is a unique combination of the constituent elements that is interdependent to produce satisfaction for tourists. A destination can be a combination of services and «locally-provided» unique experiences.

According to Rajesh $(2013$, p. 68), destination image encompasses cognitive image components, which refers to beliefs, impressions, ideas, perceptions, and knowledge that current and prospective tourists hold about various elements that are specific to the destination. Destination image has two components, the organic and induced. Organic images are formed by individual tourists themselves through past experiences with specific tourism destinations and unbiased sources of information. On the other side, induced images are created through information received from external sources, which can include destination advertising and other forms of promotions.

Identity: Rummens (1993), Beller and Leerssen (2001), Weinreich and Saunderson (2003), and Oyseman (2007) found that identity is the concept of quality, belief, and values that make a person or group different from others. It also refers to the unique sense of self and mutual feeling in awareness in each individual and it also means social relations with other groups to define who «l» am. Identity is like two sides of the same coin: one side is feeling unique, while the other is feeling the same as everyone else. Therefore, identity is one's self-image, or desired image, due to inputs from outside sources. In addition, identity is given meaning via symbolic systems regarding identity position. This is, at its core, the individual characteristics of a brand image. In marketing, Aaker (1996) explained that the structure of brand image is composed of core identity and extended identity. The core identity is the brand essence of the product. It remains firmly with the product. It is like the heart that reflects the soul of the brand, based on beliefs and values that will drive the brand to its maximum potential. The extended identity includes the other peripheral pieces to the puzzle that support the heart or essence of the product and make up the total brand.

The stakeholder: Sheehan and Ritchie (2005) defined stakeholders as the group or individuals who can affect or is affected by the achievement of a corporation's purpose. Stakeholders are not only responsible for promoting the destination, but also to guide and encourage the public and private sector investment in order to develop the products. Starik (1994) stated there may be numerous levels of specificity within the definition of stakeholders, and indeed, there is some flexibility in the definition depending on the circumstances, viewpoints and specific situations.

Destination management organizations (DMOs) recognize stakeholders as being important, since «[stakeholders] depend on potential tourists and their perception of the destination». They also supply and facilitate funding, provide the tourism promotion and products, participate, as well as, support tourism programs and policy. Pike (2005) said that DMOs depend on potential tourists and their perception on the destination. The local tourism community is responsible for delivering brand promises and they have to capture and share, with the visitor, the feeling or sense of the identity towards the brand associated with a destination. Konecnik and Go (2008) emphasized that destination identity plays an important role as brand identity and assists tourism authorities in creating a strong and sustainable brand. This helps provide a vision of how the brand should be perceived. For Chang Island, there are both internal and external stakeholders. Internal stakeholders refer to people who live and work at Chang Island. These people are in both the public and private sectors, e.g. authorities of Chang Island, tour operators, marketing organizations, entrepreneurs, citizens, the Tourism Authority of Thailand (TAT) who are responsible for TAT activities in Chang Island, and the officers from local government sectors. The term «external stakeholder» refers to current and potential tourists who may visit Chang Island. 
P. Preechawong, O. Sawagvudcharee, B. G. Mujtaba. Marketing and Managing Destination Identity for Tourism Promotion: the Case of Koh Chang Marine National Park in Thailand

Image: Rope and Mether (2001) said that image is the combination of a person's experiences, attitudes, beliefs, feelings, and knowledge towards something. Rajesh (2013, p. 71) cites studies that demonstrate that destination image has a direct relationship with perceived quality, satisfaction and intention to return, and willingness to recommend others.

In general, image can be a perception in a person's mind. Buhalis (2000) said that before travelling, people go to a destination by developing the image and a set of expectations based on previous experience, word of mouth, press reports, advertisements, and common beliefs. In a similar way, Morrison and Anderson (2002) said that the definition of destination image are the sum of ideas, beliefs and impressions that a person has of a location. Bonn, Joseph and Dai (2005) explain that destination image is influenced by the environmental attributes and atmospheric attributes such as landscapes, historical attractions, infrastructure, accommodation, facilities, and service attributes. Tourism managers can use these characteristics to manage the formation of a destination image by potential tourists. In marketing, Aaker (2002) said brands have dimension and structure and can be divided into four different perspectives: the brand as a product, the brand as an organization, the brand as a person, and the brand as a symbol. The objective of these different perspectives is to help when considering the different elements and patterns of the brand, which help in differentiating, clarifying, and enriching an identity.

We can say that destination image is former experiences in the mind of a person. The products, services, and organizations which consist of beliefs, feelings, and knowledge of the destination influence a tourist's decision to choose to travel to Chang Island. A clear, powerful image of Chang Island in tourists' minds will more likely occur when effective and consistent communication occurs across a long period whereupon, understanding and feeling of the essence of Chang Island embeds in the mind of the potential tourist.

Brand personality: Murase and Bojanic (2004) defined brand personality as a set of human characteristics. Tybout and Stephen (2005) said there is a relationship between consumers and the brand if the brand personality characteristic matches consumer demand. If the brand can express consumers' social status, they will feel more familiar and more content with the brand (Aimkij and Mujtaba, 2010). Harris and Chernatony (2001) explained that brand personality can help strengthen the synergy between its market positioning and throughout the branding process. Aaker (1997) states that the personality set is based on five dimensions: sincerity, excitement, competence, sophistication, and ruggedness. It can be concluded that brand personality creates the difference of a particular brand product from its competitors. The study of inbound tourists' attitude toward the personality of KCMNP can help us understand the status of the destination in tourists' perception. This data can be used to form guidelines for the creation of an improved destination identity.

Marketing strategy: Tourism destination and marketing place are exciting as well as challenging. Fyall, Callod and Edwards (2003) stated that tourism destinations should develop a unique position, identity, and welcoming personalities in a highly competitive environment at both national and international levels. Strategic marketing planning takes place in a rapidly changing environment, because tourists today are more educated, demanding and experienced as well as more sensitive to environmental and social issues. They have more and quicker access to information and online media that they can connect to from home and office. The marketing strategy for tourism destination has evolved from the broad recommendations to specific and segmented tourism planning. The tourism planning process reflects the vision, goals and objectives of the main plan. This means that the marketing strategy for tourism destination cannot be risky, and marketing without destination development is risky. Furthermore, destination development without marketing strategy is often futile. The marketing strategy should involve integration with the regional tourism plan and the local strategic plan. Modern marketing strategy is the marketing mix, also called the 8P's approach, which require the concept of Integrated Marketing Communication (IMC), which focuses on the consistency of messages 

Promotion: the Case of Koh Chang Marine National Park in Thailand

being communicated to all stakeholders, especially external customers. Morrison (2002) said that the critical components that determine the demand for destination product are collectively known as the marketing mix. Several different marketing mix structures have been proposed, a popular one being the 8P's model, which refer to place, people, packaging, promotion, product, price, programming, and partnerships (Weaver and Lawton, 2006).

Marketing strategy is necessary for developing a strong business which is the analysis, policies and rules of the firm in response to changing environmental and competitive conditions. Marketing strategy consists of four main components which are analysis, planning, implementation, and evaluation. In addition, marketing strategy includes all basic, short-term, and long-term activities in the field of marketing. The process usually starts with a survey of internal and external business environments and it includes understanding any inherent strategic limitations. Moreover, strategies often specify how to modify the marketing mix. This analysis of destinations is important for strategic marketing planning and positioning of a destination.

Marketing strategy is important for globalizing KCMNP. It helps to analyse the environment and competitors by using marketing mix. To develop the tourism destination, we must have both internal and external goals to generate a sustainable stream of revenue. All sectors must work together to create potential competiveness. In terms of the competition in tourism we focus on tourists' recognition, where they can easily recognize and remember the attraction by its uniqueness. It is important to determine the destination identity when developing strategic marketing plans for a particular destination and service marketing strategy, because of the potential to increase positive tourist recognition, loyalty to it, and ultimately, increased satisfaction. Research has proven that «tourist satisfaction is considered one of the prime variables to sustain competitive business in the tourism industry because it affects the choice of destination, consumption of products and services» (Rajesh, 2013, p. 70). The goal is to create loyal customers as these are individuals who re-buy a brand or tourism experience, tend to only consider that specific brand without shopping at competitors, and usually do little to no brand-related information seeking. According to Hallak, Assaker and Lee (2015) and other researchers, destination or place identity is a person's cognitions, beliefs, perceptions, and thoughts that the self is invested in a particular spatial setting. Furthermore, «Place identity theory argues that a person's place identity is more than an attachment to place; it is a complex cognitive structure as well as being a substructure of the individual's self-identity» (Hallak, Assaker and Lee, 2015, p. 38). Of course, regardless of whether we are consciously aware of it or not, place identity tends to influence what we see, think, and feel during our interactions with the physical world. The component of place or destination identity, according to Aaker (1997) involves six components, included in Figure 1. These components are destination culture, character, personality, name, logo, and slogan.

1. Destination culture is the people aspects (spirit, traditions, events, etc.), and the features of country (historical sites, monuments, archaeological sites, etc.). It can be considered an essence of the destination.

2. Destination character relates to its internal constitution, which is perceived in terms of integrity, trustworthiness, and honesty (Upshaw, 1995). This is the promise of the brand to deliver the experience associated with its distinctive value proposition.

3. Destination personality, as defined by Aaker $(1996,1997)$, is the set of human characteristics that are associated with the destination. It includes several characteristics, such as sincerity, excitement, competence. Moreover, it also embodies gender, age, socioeconomic class, as well as human personality traits such as warmth and sentimentality.

4. Destination name is often the original name of the destination, and it is strongly related to communication strategy on tourist targets. Destination name should have many strengths and unique associations. It should be distinctive, pronounceable and recallable (Keller, 2003b). 
P. Preechawong, O. Sawagvudcharee, B. G. Mujtaba. Marketing and Managing Destination Identity for Tourism Promotion: the Case of Koh Chang Marine National Park in Thailand

5. Destination logo and symbol are fundamental elements used to define a destination. A beautiful view, a famous monument or unique traditions are examples of symbols that in destination case could be the main logos to communicate a clear and distinctive value proposition compared to other competitive places.

6. Destination slogan represents a promise that a business player defines to the tourist targets. It is based on the main functional, emotive or experiential attributes of the destination, related to the benefits and values provided by the place offering.

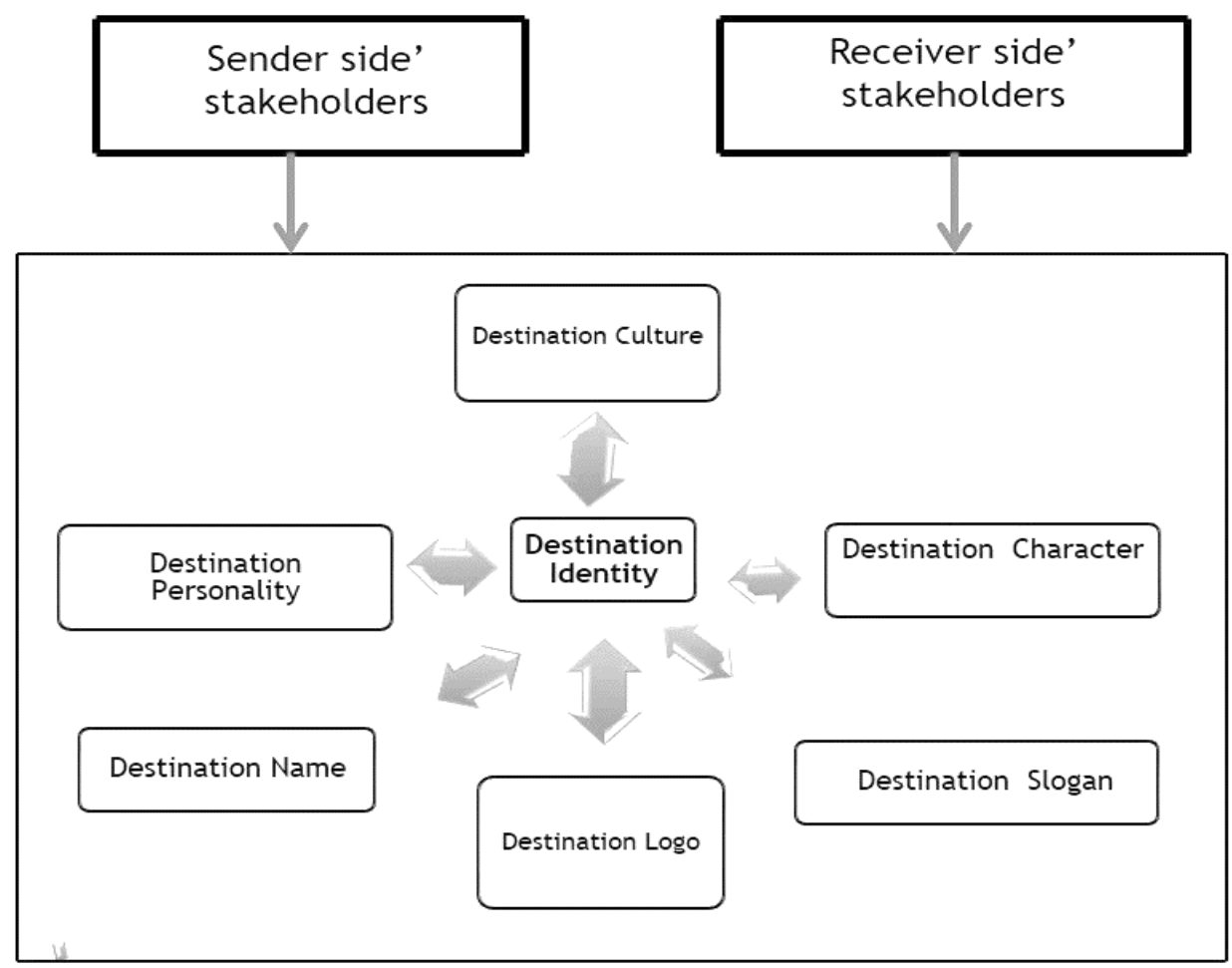

Source: adapted from Aaker, (1997).

Figure 1. Destination Identity Model

The six elements are essential in generating an effective destination identity to represent the brand or identity of the destination. It is also important to analyse its cohesiveness which depends on the consistency of these elements (Keller, 2003a). The six elements model is a known and tested method for generating a unique and powerful tourism destination identity. Good destination identities help tourists recognize and remember the differences between competing destinations when making travel decisions. Therefore, creating a unique, powerful and appropriate destination identity should be a significant way to encourage potential visitors to choose a nice destination for their vacation holiday.

Methodology and research methods. This research uses the case study approach through a qualitative methodology. The study focuses on the research question of «What are the key components of destination identity of Koh Chang Marine National Park?». The objective is to better understand the perception of stakeholders about KCMNP using interview questions as a base for a conceptual research framework. The question base for the destination identity model relies on the «six dimensions» concept, 
which are culture, character, personality, name, symbol, and slogan. We collected data between 15 January 2016 to 15 April 2016 and limited responses to focus on this specific study exclusively. Consequently, the researchers decided to interview fifty people from the sender side and receiver side of KCMNP's stakeholders. The population consists of individuals in Koh Change Marine National Park (KCMNP) (3 interviewees), Tour operators (4), Marketing organizations (2), Entrepreneurs (of hotels, resorts, and restaurants on Chang Island) (15), Chang Island general citizens (20), the KCMNP's Tourism Authority of Thailand (1), the Chang Island Sub district Administrative Organization (5), and tourists (50). The process of this research is qualitative through in-depth interviews with semi-structured questions using content analysis. Moreover, to be consistent and gain insights into the situation, the lead researcher used face-to-face in-depth interviews with the sender side and receiver side of KCMNP stakeholders. This is because the study needed to gather unique perspectives from each of them. Before starting the interview, the researchers asked for permission to record the session. Following the interview, the lead researcher transcribed verbatim (word-for-word) from recording, then aggregated the data to ensure confidentiality of the interviewees. Those data were used for this research only and no individual interview records have been archived for outside access nor are they available. This study used qualitative analysis of information from data collected during 50 separate interviews from each stakeholder group. The analysis was done qualitatively, and assessment performed by content analysis. Due to the information nature of qualitative interviews for gathering information and how one issue leads to a number of other important discussions, the time spent with each respondent varied from about 30 minutes to 60 minutes.

Results. Destination identity consists of culture, character, personality, name, and symbol. The questions asked of all the interviewees and respondents along with the rationale for and results of the findings based on content analysis for this study are as follows:

1. What are the cultures of Koh Chang Marine National Park? This question analyzed and compared between sender side stakeholders (tourists) and receiver side stakeholders (tourism companies, workers, suppliers, and government offices which benefits from collecting taxes). The findings of the interview concluded that KCMNP culture refer to the people aspect and their kind hospitality; and the natural resources and environment should be the focus as they are critical to the conservation of natural resource and environment. Respondents also recognized the specific KCMNP foods associated with this Marine Park and island.

2. What is the character of Koh Chang Marine National Park? This question aimed to compare Koh Chang Marine National Park attributes to human characteristics. This question relates to the characteristics within Koh Chang Marine National Park that the stakeholders perceive in terms of integrity character consisting of first, the intact natural resource and environment; and second, weather and climate. Another important finding is the trustworthiness of access to KCMNP, which was often described as "convenient and easy» to get to. Honesty seems to be one of the main characters of the local people and their services as they were described as being nice and friendly. The different characters appear to be significant when competing with others in regard to tourism destinations.

3. What is the personality of Koh Chang Marine National Park? This question attempted to understand perceptions in terms of KCMNP personality. We found the following three traits of sincerity, ruggedness, and sophistication especially associated with the personality of the park and island. Sincerity personality of KCMNP represents the honest, wholesome, down-to-earth, and cheerful destination. Ruggedness personality is the personality that represents an outdoorsy view. Sophistication personality is their charm and modernity. Destination personality is shown to leverage the perceived image of a place and influence tourists' choice behaviour. The creation of destination personality is useful in order to plan marketing strategies and to target tourists. These traits are assessed to determine guidelines for promoting tourism consistent with the personality perception of tourists. 
P. Preechawong, O. Sawagvudcharee, B. G. Mujtaba. Marketing and Managing Destination Identity for Tourism Promotion: the Case of Koh Chang Marine National Park in Thailand

4. What is the original name of Koh Chang Marine National Park? Uniformity regarding the name(s) of the destination is important for creating a good communication strategy in tourism development. The respondents agreed that the destination name should be distinctive, pronounceable, and easily recalled by the tourist. Our respondents in this study agreed that the name of Koh Chang Marine National Park is easy to pronounce, and they were able to easily recognize it, both of which helps tourists retain the information for brand recognition and future trips to this island. Tourists were able to recall the name of Koh Chang, and it triggered specific images in tourists' minds. Furthermore, the name is easy to use when describing their personal experiences in the island to others by word of mouth. The name of KCMNP is unique, and associated with the acronym «CHANG» (as in Koh Chang):

- $\mathrm{C}=$ Completeness

$-\mathrm{H}=$ Historical attraction

- $\mathrm{A}=$ Agro-tourism

- $N=$ Natural attractions

- $G=$ Green tourism

5. Does Koh Chang Marine National Park have a slogan? Slogans can tell customers what the product is like. Thus, a slogan for Koh Chang Marine National Park should convey an image in the mind of the tourist that quickly captures the "Koh Chang experience». It is based on the main functional, emotive and experiential attributes of the destination. Respondents knew that KCMNP's slogan is «Oriental Eden», which is associated with a destination for «completeness and natural». The slogan will help tourists remember, understand, and confirm the intent of senders. Any slogan for KCMNP must be easy to remember and convey, very quickly, the destination identity.

6. What should be an ideal logo for Koh Chang Marine National Park? This question aims to raise awareness of interviewees about the importance of a logo for Koh Chang Marine National Park. Respondents agreed that a well-designed logo will help tourists remember the destination identity and recall its name. A logo is a fundamental element in defining a destination. The logo of KCMNP consisted of three aspects: concrete, abstract and colours. The concrete elements of KCMNP logo is elephant picture, coral, sea, and yolk. Abstract elements of the logo include paradise, happiness, peace, and relaxing. Main colours are green and blue. Composition colours are yellow, orange, white, grey, and brown. These are the main elements of logo for KCMNP that could be used in the main visuals to communicate a clear and distinctive value proposition compared to other competitive places.

Figure 2 encapsulates and represents the main guidelines for marketing management in three aspects: the positioning, the characteristics of target group, and the plan for creating/managing the destination identity for tourism promotion. The positioning is determined using basic factors (urbanization/nature), product presentation, and tourism services (simplicity/luxury).

KCMNP is a great place for diving; therefore, the characteristics of quality target groups for tourism destination can be summed up into the following six groups: friendship, romance, family, relaxation, isolation, and divers. Guideline for creating and managing destination identity for effective and sustainable performance are based on sustainable tourism and experienced leadership (U-tantada et al., 2019). Marketing mix of 8P's (Kotler and Armstrong, 2005) is one of the useful tools for marketing and managing of a destination. The 8P's include place, people, packaging, promotion, product, price, programming, and partnership. Overall, KCMNP is accessible to tourists all year round with interesting events planned for nearly every month. These planned activities should be supported by all local stakeholders since «tourism entrepreneurs» place identity has a significant direct effect on both entrepreneurial self-efficacy (ESE) and support for community (SFC)' (Hallak, Assaker and Lee, 2015, p. 37). This is helpful for tourists and attracts them and promotes the island. The sender side stakeholders should be setting tourism calendar as per their major tourism plans and prepare activities according to the planned calendar. 


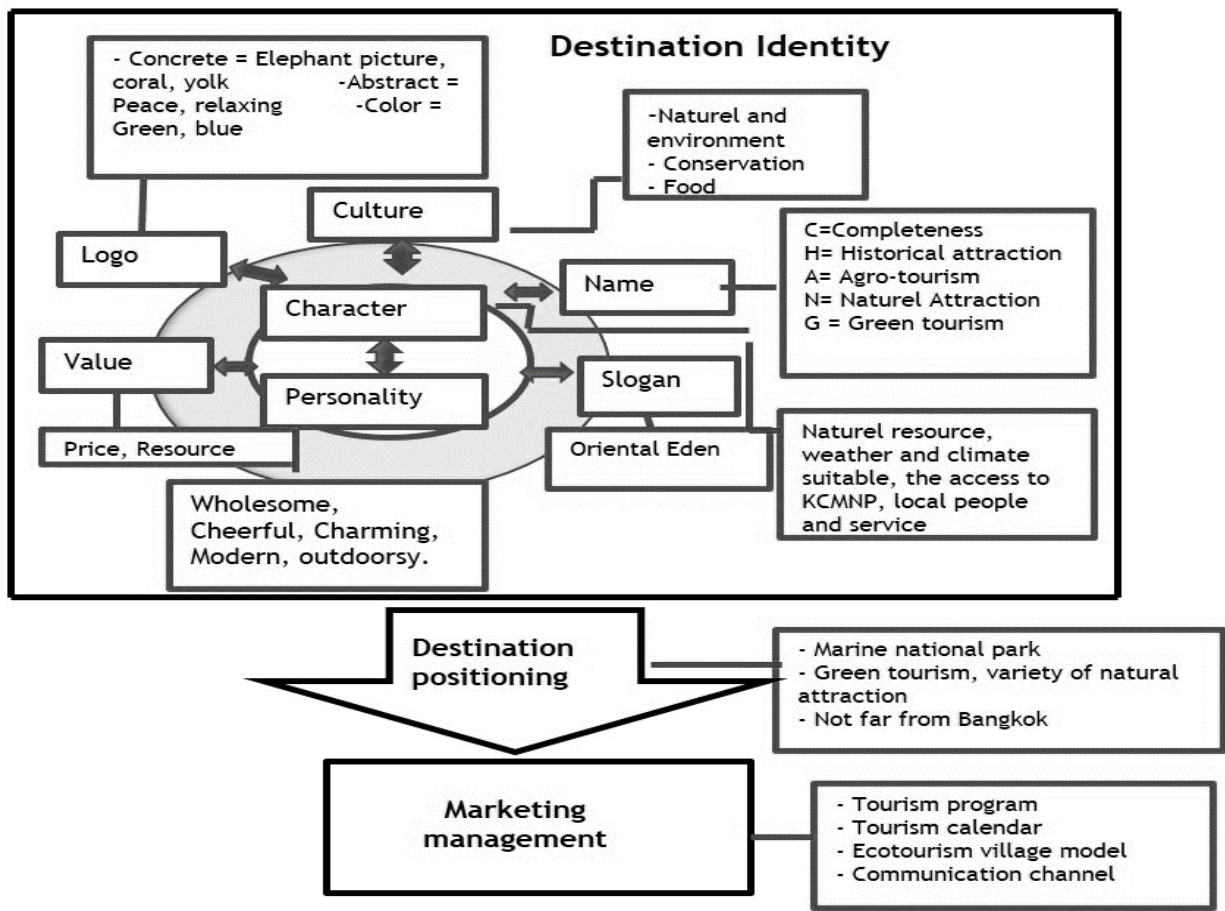

Figure 2. Guideline for Marketing Managing Destination Identity

Source: created by the Authors.

KCMNP is effectually pronounced as "green tourism» and eco-friendly tourism, which means villages should be aware of laws, regulations, and best practices about the protection of natural resources. They should not damage natural resources and environment, but also ecotourism villages' model is important in term of eco-friendly tourism. Corporate social responsibility in this island means all small and large businesses alike must focus on the delivery of eco-friendly green tourism, sustainability, and conservation through ethical and transparent communication with all stakeholders (Cavico and Mujtaba, 2008). Tourism agencies should provide relevant orientation and training programs to enhance the performance of each employee and business since research has demonstrated that there is a «direct relationship between entrepreneurial orientation and enterprise performance» (Hallak, Assaker and Lee, 2015, p. 37). Open communication channels by all project managers or marketers along with the ethical treatment of visitors are especially important for effective brand development for any nation and city (Afzal, Khan and Mujtaba, 2018; Maliwan and Mujtaba, 2012; Janasak and Mujtaba, 2012). Most tourists come to KCMNP through word-of-mouth advertisements. It is the basis of effective advertisement and efficiency. Celebrity marketing is using a celebrity or well-known people to stimulate interest for a tourism destination. KCMNP falls under the control of National Park, Wildlife and Plant Conservation Department, and its main function is conservation of nature and environment.

KCMNP technology orientation and application seems modern and should focus on «glocalization» by connecting data between global and local perspectives together. The tourists can search the important data on KCMNP through modern search engines and tourism software applications. Research has demonstrated that «new product development, online promotions, and an entrepreneur's level of education are significantly related to enterprise performance» (Hallak, Assaker and Lee, 2015, p. 37). 
P. Preechawong, O. Sawagvudcharee, B. G. Mujtaba. Marketing and Managing Destination Identity for Tourism Promotion: the Case of Koh Chang Marine National Park in Thailand

As mentioned before, this study has gained significant insights into the situation behind the lacklustre arrival numbers of KCMNP. We have identified some of key issues that will serve as guidelines to assist in the development of suitable strategies for generating a strong and sustainable destination brand. Based on recommendations of previous researchers (Keller, 2003b), we know that any destination name should be associated with many strengths and unique associations, while being distinctive, pronounceable, and recallable. The good news for the local stakeholders (receivers) is that KCMNP seems to fit most of these requirements. As researchers, we recommend that the receiver stakeholders should continue to work on the five personality dimensions (Aaker, 1997) of sincerity, excitement, competence, sophistication, and ruggedness as these traits can differentiate the island from its national and international competitors in a sustainable manner over time. The island entrepreneurs, managers, and public sector policy makers should continue to make the KCMNP more value-added, stronger, better, and different from the competitors each year by having good orientation and training programs (Mujtaba, 2008). We know that different is not necessarily better, but better is always different from most others. As such, the marketing strategies for KCMNP should help in its brand being perceived as «different» and a more valuable destination in the minds of its visitors and future tourists (Mujtaba, 2014).

Through this research, we found that the key components of KCMNP consisted of the following results and communication channels:

1. KCMNP has a destination culture where conservation is very important and seems to be the fabric of the social community for local inhabitants and small business owners.

2. Destination character meant that hospitality must be strong, consistent, and a constant phenomenon.

3. Destination personality is modern and sincere which creates welcoming experiences for all tourists.

4. Destination name "CHANG» is widely known to the local business owners and employees as referring to completeness, historical attraction, agro-tourism, naturel attraction, and being focused on green tourism.

5. Destination logo is unique, distinctive, and memorable; as such, it should be included in all training sessions and promotional communication messages.

6. Destination slogan of «Oriental Eden» is something that must be delivered consistently in order to create satisfaction and meet tourist expectations.

7. Destination value must be sustainable and satisfactory in the perception of the tourists visiting the island.

8. Tourism product is used in positioning of the destination which comprise of the 8P's marketing mix model:

- place should be the focus of all communication channels;

- product must be sustainable green tourism;

- price or the cost of tourism should be a good overall value and kept to a minimum as per the perception of visitors;

_ promotion could be all events that create a recognized brand for the destination;

- programming should include daily fun and weekly activities that create memorable «wow» or delightful experiences for all visitors;

- packaging can include a series of tourism activities in a given calendar during a specific day, week and month;

- people research pointed out to the idea of engaging local citizens who offer services and hospitality that is consistent with the promotional brochures; 

Promotion: the Case of Koh Chang Marine National Park in Thailand

- partnership can include local citizens, small businesses, public sector officials, police officers, and tour companies that are part of the value chain in delivering a great tourism experience for all visitors.

These communication channels can help in sending consistent messages, data and information to tourists until they become fully familiarized with the KCMNP image. According to Hallak, Assaker and Lee $(2015$, p. 45), four identity principles are continuity, distinctiveness, self-esteem, and self-efficacy; local leaders and business owners should attempt to be consistent in associating each tourist's experience with these identity principles using effective communication channels. Based on this research, the main tools for effective promotional communication for KCMNP are word of mouth, celebrity endorsements, corporate social responsibility or green tourism, and delivering delightful or value-added holiday experiences. As researchers, we emphasize that the guideline for marketing managing of destination identity for all business owners in the KCMNP Island should comprise of at least three sectors: local people, government, and entrepreneurs. The inspiration and intentions of local people, government leaders, and small business entrepreneurs are critical tools for effectively achieving the goals of tourism destination in a sustainable manner. The stakeholders of KCMNP must work together in clarifying, creating and guiding their motivations, emotions, and promotions consistently to their employees as well as current and future visitors. The motivation or motives for why KCMNP must become a destination of choice should be clarified and consistently communicated to all stakeholders. Emotions represent the motivation of employees, policy makers and citizens to sustain the KCMNP energy toward a specific direction over time in order to make their city a valuable tourism destination. Promotional strategies should be supported by strong emotions and motivations for why tourists should make KCMNP their destination of choice.

Conclusions. This study aimed to gain insights into the truth behind the lacklustre arrival numbers of tourists, and to explore the perception of the sender side and receiver side of Koh Chang Marine National Park's stakeholders. This should help the researchers identify key issues that will facilitate development of suitable guidelines to generate a strong, and viable destination identity for marketing. Analysis of resources, competencies, and capabilities of the local staff are the basis from which the destination brand identity can be developed. «Encouraging engagement between tourism entrepreneurs and the local community through building social networks can create mutual benefits for the community and the business owners» (Hallak, Assaker and Lee, 2015, p. 47). The literature on the topic of destination identity comes from the perception of several stakeholders about the potential of destination tourism combined with the view of tourists. A destination is a combination of services and locally provided experiences. In addition, the core identity is the brand essence of the product, which for this study was tourism. The specific guidelines for promoting KCMNP are creating activity tourism programs, setting a tourism calendar, establishing an ecotourism village model, and opening more consistent and integrated communication channels. Overall, this research paper is a specific study on the development of tourism destination identity for this east-Asian region; other researchers can use the findings as a guideline for developing tourism destination identities for their cities to attract loyal and repeat visitors. Recommendations for a future study are to compare and analyse the advantages of each tourism destination with other marine tourism destinations. Some studies have demonstrated that women have a higher level of attachment to certain destinations and places than men (Hidalgo and Hernandez, 2001). Furthermore, research shows that «Men appear to have consistently higher levels of entrepreneurial self-efficacy than women, even in cases where both groups are well educated» (Hallak, Assaker and Lee, 2015, p. 39); as such, future researchers can attempt to determine if there are differences in the views of males and females regarding tourism destinations and promotional effectiveness.

Author contribution. conceptualization, methodology, investigation, writing - P.P., O.S., B.G.M.; supervision and project administration - O.S., B.G.M. 
P. Preechawong, O. Sawagvudcharee, B. G. Mujtaba. Marketing and Managing Destination Identity for Tourism Promotion: the Case of Koh Chang Marine National Park in Thailand

\section{References}

Aaker, D. A. (1996).Crandone administrando marcas de sucesso, Fu-tura, São Paulo.

Aaker, J. L. (1997). Dimensions of Brand Personality. Journal of Marketing Research, 34, 347-56.

Aaker, D. (2002). Building strong brands. London: Free Press.

Afzal, A., Khan, M. M., and Mujtaba, B. G. (2018). The Impact of Project Managers' Competencies, Emotional Intelligence and Transformational Leadership on Project Success in the Information Technology Sector. Marketing and Management of Innovations, 2, 142-154.

Aimkij, N. and Mujtaba, B. G. (2010). Branding and Brand Equity Measurement in the Beer Industry of Thailand. Chinese Business Review, 9(4), 01-16.

Beller, M. \& Leerssen, J. (2001). Identity, Imagology. A Handbook on the literary representation of national characters. (Note: some articles are available at the Handbook's part of the IMAGE website: www.cf.hum.uva.nl/images/dtory.identity.pdf).

Bregoli, I. (2012). Effects of DMO Coordination on Destination Brand Identity: A Mixed-Method Study on the City of Edinburgh. Journal of Travel Research, 52(2), 212-224.

Bonn, M., Joseph, S. \& Dai, M. (2005). International versus domestic visitors: An Examination of Destination image perceptions. Journal Travel Research, 43(3), 294-301.

Buckley, R. C. (2010). Adventure tourism management. International centre for ecotourism research. Griffith University. Gold Coast, Australia.

Buhalis, D. (2000). Marketing the competitive destination of the future. Tourism Management, 21, 97-116.

Cai, L. A. (2002). Cooperative Branding for Rural Destination. Annals of Tourism Research, 29(3), 720-742.

Cavico, F. J. and Mujtaba, B. G. (2008). Ethical principles and practices in human resource management. Pages 83-114.

Chapter Five in the Handbook of Hospitality Human Resource Management; edited by Dana Tesone and Abraham Pizam. Elsevier Publications: New York.

Department of tourism (2019). Website: http://www.tourism.go.th

Flanagan, J. R. \& Lederman, S. (2001). Feeling bumps and holes. Nature, 412, 389-390.

Framke, W. (2002). The Destination as a Concept: A Discussion of the Business-related Perspective versus the Sociocultural

Approach in Tourism Theory. Scandinavian Journal of Hospitality and Tourism, 2(2), 92-108.

Fyall, A., Callod, C. and Edwards, B. (2003) Relationship Marketing the Challenge for Destinations. Annals of Tourism Research, 30, 644-659.

Hallak, R., Assaker, G., and Lee, C. (2015). Tourism entrepreneurship performance: the effectives of place identity, selfefficacy, and gender. Journal of Travel Research, 54(1), 36-51.

Harris, F. \& Chernatony, L. (2001). Corporate branding and corporate brand performance. European Journal of Marketing, 35(3/4), 441-456

Hidalgo, M. C. and Hernandez, B. (2001). Place attachment: conceptual and empirical questions. Journal of Environment Psychology, 21(3), 272-81.

Huang, J. L., Ryan, A. M., and Mujtaba, B. G. (2015). Vicarious experience of justice: when unfair treatment of one's colleague matters. Personnel Review, 44(6), 826-846.

Janasak, Siraya and Mujtaba, Bahaudin G. (2012). The impact of cultural values on the entrepreneurship personality: a crosscultural comparison of Thai and Chinese business students in Thailand. RU International Journal, 6(1), 39-52. Keller, K. L. (2003a). Brand synthesis: The multidimensionality of brand knowledge. Journal of Consumer Research, 29(4) 595-600.

Keller, K. L. (2003b). Strategic brand management: Building, measuring, and managing brand equity, 2nd ed., Prentice Hall: Upper Saddle River, NJ.

Konecnik, M. \& Go, F. (2008). Tourism destination brand identity: the case of Slovenia. Brand Management, 15(3), $177-189$.

Mak, A. K. Y. (2011). An identity-centered approach to place branding: Case of industry partners' evaluation of lowa's destination image. Journal of Brand Management, 18(6), 438-450.

Maliwan, R. and Mujtaba, B. G. (2012). Tourist Attitudes toward Traveling in Thailand after the Political Demonstrations and Protests. Journal of Management and Sustainability, 2(1), 16-28.

Morrision, A. \& Anderson, D. (2002). Destination branding. Available from: www.macvb.org/intranet/presentation/DestinationBrandingLOzarks6-10-02.

Murase, H., \& Bojanic, D. (2004). An Examination of the Differences in Restaurant Brand Personality Across Cultures. Journal of Hospitality \& Leisure Marketing, 11(2/3), 97-113.

Mujtaba, B. G. (2014). Managerial Skills and Practices for Global Leadership. ILEAD Academy: Florida.

Mujtaba, B. G. (2008). Coaching and Performance Management: Developing and Inspiring Leaders. ILEAD Academy: Florida. Mujtaba, B. G. (2008). Employee orientation and mentoring programs. Pages 317-346. Chapter Fifteen in the Handbook of Hospitality Human Resource Management; edited by Dana Tesone and Abraham Pizam. Elsevier Publications: New York.

National Economic and Social Development (2019). Viewed website at: http://www.nesdb.go.th

Oyserman, D. (2007). Social identity and self-regulation. In A. W. Kruglanski \& E. T. Higgins (Eds.), psychology: Handbook of basic principles (2nd ed., pp. 432-453). New York: Guilford Press. 
P. Preechawong, O. Sawagvudcharee, B. G. Mujtaba. Marketing and Managing Destination Identity for Tourism Promotion: the Case of Koh Chang Marine National Park in Thailand

Pike, S. (2004). Destination marketing organizations. Elsevier: Amsterdam.

Pike, S. (2005). Tourism destination branding complexity. Journal of Product \& Brand Management, 14(4), 258-9.

Rajesh, R. (2013). Impact of Tourist Perceptions Destination Image and Tourist Satisfaction on Destination Loyalty: A conceptual Model. PASOS. Revista de Turismo y Patrimonio Cultural, 11(3), 67-78.

Rope, T. \& Mether, J. (2001). Towards the success of the brand: successful marketing image. Helsinki: WSOY.

Rummens, J. (1993). Personal Identity and Social Structure in Sint Maartin/Saint Martin: a Plural Identities Approach Unpublished Thesis/Dissertation: York University

Saraniemi, S. (2011). From destination image building to identity-based branding. International Journal of Culture, Tourism and Hospitality Research, 5(3), 247-254

Sheehan, L. R. \& Ritchie, J. R. (2005). Brent: Destination Stakeholders, Exploring Identity and Salience. Annals of Tourism Research, 32(3), 711-734.

Starik, M. (1994). Reflections on stakeholder theory. Business and Society, 33(1), 89-95.

Schiffman, G. \& Kanuk, L. (2000). Consumer Behavior. Prentice-Hall International.

Tybout, A. M. \& Stephen, B. (2005). Kellogg on branding. New York: John Wiley \& Sons Inc.

Upshaw, L. B. (1995). Building brand identity: A strategy for success in a hostile marketplace. New York: Wiley.

U-tantada, S., Yolles, M., Mujtaba, B. G., and Shoosanuk, A. (2019). Influential driving factors for corporate performance: A case for small and medium enterprises in Thailand. Kasem Bundit Journal, 20, 157-172.

Weaver and Lawton. (2006). Tourism Management, 3rd edition, National Library of Australia.

Weinreich, P. \& Saunderson, W. (2003). Analyzing Identity: Cross-Cultural, Societal and Clinical Contexts. London: Routledge. http:// www.Traveling.Webarchive (15.03.2016).

Паніта Прічавоне, Університет Шинават, Вища школа (Таїланд);

Оусані Савагвудчарі, Університет Шинават, Вища школа (Таїланд);

Бахаудін Г. Муджтаба, Південно-Східний університет Нова (США).

Маркетинг i менеджмент туристичної айдентики для просування туризму: на прикладі морського національного парку Ко Чанг в Тайланді

Туристична галузь Таїланду $\epsilon$ висхідною точкою при фрормування стратегії економічного розвитку країни. Питома вага туристичної галузі у ВВП Таїланду становить більш ніж 10\%. При цьому місцеве населення отримує ряд економічних та соціальних переваг від розвитку туристичної галузі. 3 іншого боку, стейкхолдери зацікавлені у підвищенні ефеективності управління туристичною галуззю за рахунок формування його айдентики. Авторами зазначено, що стейкхолдери морського національного парку Ко Чанг (KCMNP) виокремлюють вагомість такого фрактору як айдентика. KCMNP - це острівний архіпелаг в Таїландській затоці в провінції Трат у східному регіоні Таїланду (поруч із кордоном Камбоджі та майже в 8 кілометрах від берега). Розробка та використання айдентики є ключовим аспектом при фрормуванні маркетингової програми промоції туристичної галузі. Авторами доведено, що ефективне управління айдентикою формує передумови підвищення доходів KCMNP у довгостроковій перспективі, а також дозволяє місцевим громадам отримати ряд переваг, а саме: покращення умов праці, підвищення якості послуг та умов життя. У статті проведено якісний аналіз змісту ключових вимог стейкхолдерів Національного парку KCMNP. Авторами систематизовано та охарактеризовано рекомендації для підвищення ефрективності фуннкціонування Національного парку KCMNP. У статmі доведено необхідність модернізації системи маркетингу та менеджменту КCMNP за рахунок формування промоції айдентики туристичної галузі Таїланду. Ефрективна маркетингова програма промоції може призвести до зростання кількості відвідувачів щороку. у статті авторами систематизовано основні принципи формування конкурентоздатної айдентики туристичної галузі Таїланду. Авторами визначено та обгрунтовано ключові компоненти цільової айдентикки морського національного парку Ко Чанг.

Ключові слова: айдентика, зацікавлені сторони, маркетинг, управління, туризм, національний парк.

Manuscript received: 22.02.2019.

(C) The author(s) 2019. This article is published with open access at Sumy State University. 